\title{
Patterns of Exploratory /Locomotor Behaviour in Mice Following Chronic Consumption of Uncooked Beans
}

\author{
Aduema W*and Amah AK \\ Department of Human Physiology, Gregory University, Nigeria
}

Submission: November 16, 2017; Published: December 20, 2017

*Corresponding author: Aduema W, Department of Human Physiology, Gregory University, Uturu, Abia State, Nigeria, Email: Wadioniaduema@gmail.com

\begin{abstract}
The effects of chronic consumption of uncooked beans diet on exploratory/locomotor behaviour were investigated. Thirty (30) CD1 mice weighing 18-35g were randomly assigned into three groups, viz; control, uncooked beans diet ( $50 \% \mathrm{w} / \mathrm{w})$, while another set of mice were placed on serotonin precursor $(5-\mathrm{HTP})$ diet $(0.2 \mathrm{mg} / 50 \mathrm{~g} \mathrm{w} / \mathrm{w})$ respectively for thirty days. All the mice had access to clean drinking water ad libitum. Before the neurobehavioral parameters were assessed, the phytochemical analysis of the beans, LD50 of the beans) and that of the serotonin precursor (5-HTP) were determined. Serotonin concentration was measured in the beans using gas chromatography analysis. The open field maze and light and dark transition box were employed for the evaluation of exploratory/locomotor behaviour. Daily food intake, water intake and body weight change were measured. The frequency of rearing in the open field was not significantly different in the uncooked beans and serotonin precursor fed group compared to control. However, the frequency of line crosses, stretch attend posture were decreased in the test group $(\mathrm{p}<0.05)$ compared to control. This indicates a decreased exploratory/locomotor behaviour in the test group. There was also a significant $(\mathrm{p}<0.05)$ decrease in the frequency of transition in the light/dark transition box for the uncooked beans fed group when compared to the control. The administration of serotonin precursor diet (5-HTP) produced similar result as uncooked beans, thus suggesting that serotonin may be involved in the action of beans on neurobehavioral parameters. Thus, chronic consumption of uncooked beans diet decreases exploratory/ locomotor behaviour
\end{abstract}

Keywords: Uncooked beans; Open field; 5HTP; Mice

\section{Introduction}

Beans, is known to be rich in starch, protein, dietary fibres and as an excellent source of iron, potassium, selenium, molybdenum, thiamine, vitamin B6, and folate. These beans sometimes referred to as cowpeas, Southern pea, China pea, Cow-gram in United State or Niebe in French speaking Africa [13]. It has been reported that beans have anti-carcinogenic, antimutagenic [4]; anti-inflammatory, anti-diabetic, hypoglycaemic, depurative, cardio-protective and antioxidant effects [5]. It has also been reported that beans contain serotonin and its precursor 5-Hydroxytrytophan (5-HTP) [6]. Beans contain other chemical compounds including saponins, tannins, glycosides, flavonoids etc. Among the array of chemical constituents, notably, serotonin has neuro behavioural actions such as mood, memory, learning, and sleeps [6]. Since beans contain neurotransmitters and chemicals that can potentially affect behavioural patterns, it may be worthwhile to find out whether chronic consumption of uncooked beans diet can affect behaviour. This was of particular interest when we consider the challenges that confront human behaviour and how behavioural disorders still remain a global concern [7]. It is conceivable therefore that chronic consumption of beans (uncooked) diet can affect behaviour.

\section{Materials and Methods}

\section{Experimental animals/grouping}

Thirty (30) adult Swiss white mice weighing between 15$30 \mathrm{~g}$ obtained from the disease -free stock of the animal house, Department of Physiology, University of Nigeria, Nsukka were used for this research work. The animals were randomly assigned into three (3) groups of ten (10) animals per groups. The animals in the control group received normal rodent feed (rodent chow) only, while the test group received mixed feed of $50 \mathrm{~g}$ of uncooked beans per every $50 \mathrm{~g}$ of rodent chow making $50 \%$ of the beans diet and $(0.2 \mathrm{mg} / 50 \mathrm{~g})$ serotonin precursor diet for 30 days.

\section{Experimental design}

The open field maze and light/dark transition box was used to access locomotor/exploratory behavior. 
The open field test was used to provide measures of locomotion, exploration and anxiety [8]. The experiment was performed in an enclosed laboratory to screen the animals from noise and provide dim light to avoid distraction of the animals. The animals were placed in the centre of the maze and allowed to explore the open field for 5 minutes. Before introducing each animal; the floor of the maze was cleaned using 70\% ethyl alcohol in order to eliminate olfactory influences. The following behaviours were scored during the 5 minutes to assess locomotor and exploratory behaviours: line crossing, rearing and stretch attend posture. Also, the light and dark transition box is a test of locomotion and exploratory behaviour. Each mouse was picked up using a plastic bucket and placed in the centre division of the large compartment facing the floor. The mouse was allowed to explore the transition box for 5 minutes. Entering into the chamber is defined as the placement of all four paws into the chamber. During the period of 5 minutes, behaviour scored using a stop watch was frequency of transition.

\section{Statistical analysis}

Data collected were expressed a Mean \pm SEM (standard error of mean), analysis of variance (ANOVA) and the student ' $t$ ' test were used for analysis. "P" value less than 0.05 , was considered statistically significant.

\section{Results}

Figure 1 compares the frequency of line crosses in the three groups of mice. The horizontal locomotor behaviour following consumption of uncooked beans, 5HTP and control diet was measured by the number of lines crossed by the animals (mice) within five minutes in the open field maze. The number of lines crossed by the mice were, $73.43 \pm 3.60$ (control), $64.88 \pm 0.89$ (uncooked beans) and $53.43 \pm 2.00$ (serotonin precursor). The statistical analysis shown in the graph of Figure 1, shows that the frequency of line crosses of the uncooked beans and serotonin precursor fed mice was significantly lower $(\mathrm{P}<0.05)$ compared to control. However, the frequency of line crosses of the serotonin precursor fed mice was significantly lower $(\mathrm{P}<0.01)$ compared to the uncooked beans group (Figure 1).

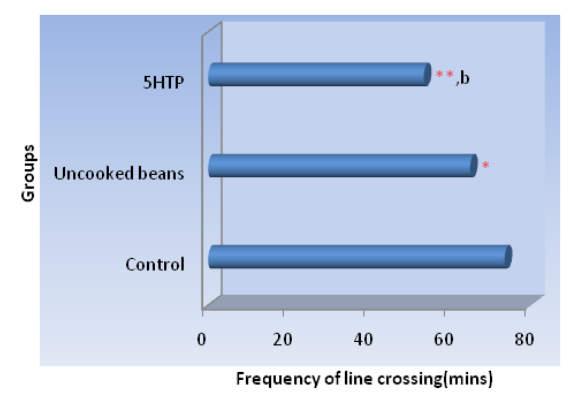

Figure 1: Frequency of line crossing in the different experimental groups during the open field test. Values are expressed as are expressed as mean \pm SEM, $n=10,{ }^{*} p<0.05$ vs. control; ${ }^{* *} P<0.01$ vs. Control, $b=p<0.01$ vs. uncooked beans.
Rearing and walling are forms of exploratory behaviours as well as vertical locomotor activity. The frequency of rearing in the open field for control mice beans were, $2.33 \pm 0.94$ (control), $1.88 \pm 0.88$ (uncooked) beans and $2.57 \pm 0.48 / 5$ mins (serotonin precursor) respectively. The graph in Figure 2 shows that the frequency of rearing among the groups, when compared was significantly not different (Figure 2).

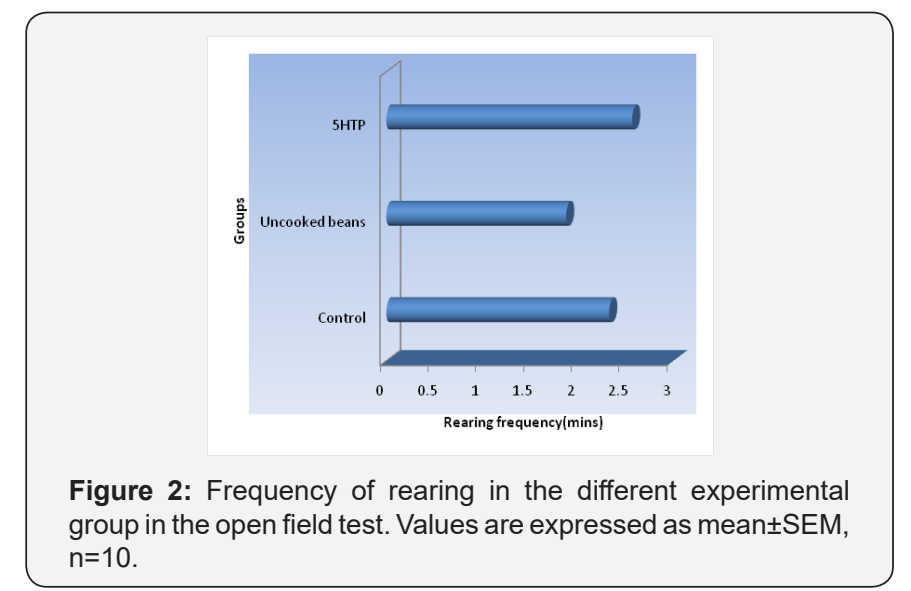

Figure 3 compares the frequencies of the stretch attend posture (SAP) which is a measure of anxiety and exploration in the three experimental groups. The values are: $2.40 \pm 0.39$ (control), $1.88 \pm 0.52 / 5 \mathrm{mins}$ (uncooked beans) and $1.57 \pm 0.53$ (serotonin precursor). The frequency of stretch attend posture of the uncooked beans and 5HTP group was significantly lower $(\mathrm{p}<0.05)$ compared to control. However, those fed with the serotonin precursor diet was significantly lower compared to the uncooked beans group (Figure 3).

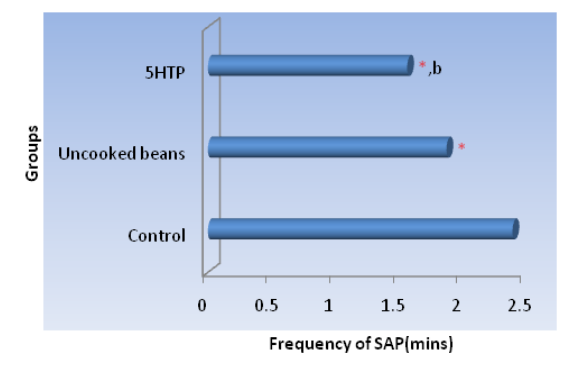

Figure 3: Frequency of stretch attends posture in the different experimental groups during the open field test. Values are expressed as mean \pm SEM, $n=10,{ }^{*} p<0.05$ vs. control; $b=p<0.05$ vs. uncooked bean.

The frequency of transition (that is the number of time the animals passes into the opposite compartment) between the four experimental groups is in Figure 4. The values are: $16.70 \pm 1.46$ (control), 8.88 $\pm 2.02 / 5$ mins (uncooked beans) and $5.43 \pm 0.65$ (serotonin precursor). The frequency of transition of the uncooked beans group of mice was statistically lower $(p<0.01)$ compared to control. However, the serotonin precursor fed mice had a significantly lower $(\mathrm{p}<0.001)$ frequency of transition compared to control group (Figure 4). 


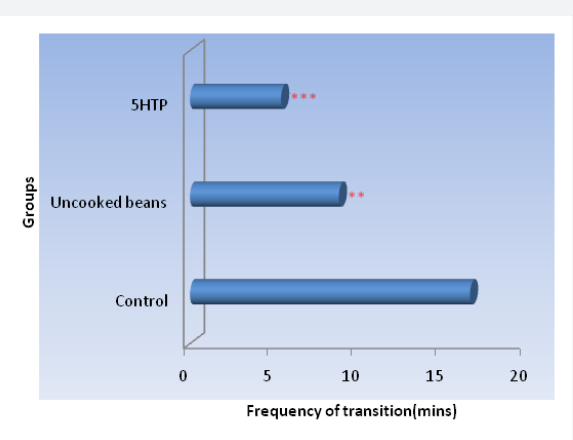

Figure 4: Frequency of transition in the light/dark transition box test. Values are expressed as mean \pm SEM, $n=10,{ }^{* *} p<0.01$ vs. control; ${ }^{* * *}=p<0.001$ vs. control.

\section{Discussion}

Locomotors activity and exploratory behaviour can be used to observe neurobehavioral activities in mice and rats using the open field maze test and the light /dark transition box Walsh \& Cummins [8]. Behaviour such as the number of line crosses and the frequency of rearing in an open field apparatus are used as measures of loco motor activity but are also measures of exploration and anxiety. A high frequency of these measures indicates increased locomotion and exploration and/or a lower level of anxiety Walsh \& Cummins [8]. Stretch attends posture (risk assessment behaviour), grooming, defecation and urination can also be used as behaviour scores in neurobehavioral experiments Espejo [2]. Also, the light/dark transition box test is a measure of locomotion and exploration in addition to anxiety.

In the open field maze test, the frequency of line crosses of the uncooked beans and the serotonin precursor (5-HTP) group of mice were significantly lower compared to the control. Similarly, the frequencies of stretch attend posture in the uncooked beans and serotonin precursor group of mice were also significantly different compared to control. This indicates a lower locomotor and exploratory activity in the uncooked beans and serotonin precursor (5-HTP) groups of mice and higher in the control group. The frequency of rearing did not differ among the groups. In the light/dark transition box test, the frequency of transition, that is, the number of times the animal enters in and out of the light/Dark box was significantly lower in the uncooked beans and serotonin precursor group of mice compared to the control group. Thus, indicating decreased locomotor/exploratory activity in the uncooked beans and serotonin precursor groups when compared to the control group. Locomotion is controlled by the central pattern generators in the spinal cord Osim [9]. It is conceivable therefore, that the uncooked beans which contain serotonin and its precursor, (5-HTP) may have an inhibitory influence or effect on the motor areas of the nervous system such as the motor cortex, cerebellum or spinal cord which in turn caused the decreased locomotor/exploratory activities.

\section{Acknowledgement}

We acknowledged Pa and Mrs. BA Aduema, Mr. Iwasam Joshua, Prof. EE Osim and Assc Prof. AA Nwankwo for their priceless support.

\section{References}

1. Henshaw DR, Attia E, Bhargava M, Hannafin JA (2008) Competitiveness of cowpea-based processed products. Journal of Orthopaedic Research 24(3): 481-490.

2. Sigh AK, Rachie E (1997) Epidemiology of black eye beans mosaic virus. Indian Journal of Virology 13: 143-145.

3. Kay DE (1979) Food legumes. Tropical Products Institute, Ministry of Overseas Development, p. 435.

4. Gref E, Eaton JW (1993) Suppression of caloric cancer by dietary phytic acid. Nutr Cancer 19(1): 11-19.

5. Bennick E, Maurice O, Elizabeth R (2008) Beans \& Health: A comprehensive Review. Frazee, Minnesota, USA.

6. Brunton LB, Lazio JS, Parker KL (2005) Therapeutics. The Pharmacological Basis of Therapeutics (607-629). McGraw-Hill, New York, USA.

7. Messman T (2005) Psychiatric drugs: Chemical warfare on humans: Interview with Robert Whitaker.

8. Walsh RN, Cummins RA (1976) The open field test: a critical review. Psychol Bull 83(3): 482-504.

9. Osim EE (2008) Neurophysiology. University of Calabar Press, Calabar, Nigeria, pp. 24-27.

\section{Your next submission with Juniper Publishers will reach you the below assets}

- Quality Editorial service

- Swift Peer Review

- Reprints availability

- E-prints Service

- Manuscript Podcast for convenient understanding

- Global attainment for your research

- Manuscript accessibility in different formats

( Pdf, E-pub, Full Text, Audio)

- Unceasing customer service

Track the below URL for one-step submission https://juniperpublishers.com/online-submission.php 